\title{
Diagnosis and Recommendation Integrated System Norms and Sufficiency Ranges for Tomato Greenhouse in Mediterranean Climate
}

\author{
Alfonso Llanderal and María Teresa Lao \\ Agronomy Department of Higher Engineering School, University of Almeria, \\ Agrifood Campus of International Excellence ceiA3. Ctra. Sacramento $s / n$, \\ La Cañada de San Urbano, Almería 04120, Spain
}

Juana Isabel Contreras and María Luz Segura'
Institute of Research and Training in Agriculture and Fishery (IFAPA), Junta
of Andalusia, La Mojonera, Almería 04745, Spain

Additional index words. diagnostic and recommendation integrated system, foliar diagnostic, leaves analysis, nutrient ratio, phenological stage

\begin{abstract}
The objectives of this study were to compute diagnosis and recommendation integrated system (DRIS) norms and sufficiency ranges from a survey of tomato crops grown in Mediterranean greenhouses and the verification of their variation during plant growth and development. DRIS norms were computed from 408 samples of first young mature leaves collected during different phenological stages. Using the DRIS technique, two sufficiency ranges were developed: one includes all the database regardless of the phenological stage, and the other was developed based on the phenological stage. Also, ten DRIS norm nutrient ratios and $\mathrm{CV}$ were computed from $\mathrm{N}, \mathrm{P}, \mathrm{K}, \mathrm{Ca}$, and $\mathrm{Mg}$ analytical results. All the ratios in flowering (FL), and only $\mathrm{N} / \mathrm{K}, \mathrm{Mg} / \mathrm{K}$, and $\mathrm{Mg} / \mathrm{N}$ in fruit development (FD), showed low $\mathrm{CV}$ and therefore may play a fundamental role in crop development in accord with the DRIS norms calculated. It is also necessary to point out that a slight modification in the nutrient concentration led to a large change in the nutritional balance of the plant. Moreover, the general sufficiency ranges developed were: $\mathrm{N}$ (25-48), P (2.6-4.7), K (16-31), Ca (23-36), and $\mathrm{Mg}\left(6.7-10 \mathrm{~g} \cdot \mathrm{kg}^{-1}\right)$. In conclusion, this work may signify an improvement in the nutritional diagnosis of greenhouse tomatoes in the Mediterranean area, because there is great variability when setting DRIS standards and sufficiency ranges based on phenological stages compared with general DRIS norms and sufficiency ranges. Use of DRIS norms and sufficiency ranges will allow better nutritional adjustment based on the phenological stage of the crop.
\end{abstract}

Tomato is one of the most important greenhouse vegetable crops in greenhouses in Almeria, with a production area of 8700 ha (Cabrera et al., 2016). In this area, the most usual cropping techniques are sand-mulched soil, fertigation, and the use of irrigation with groundwater which has the following characteristics: high electrical conductivity (from 2.0 to $4.5 \mathrm{dS} \cdot \mathrm{m}^{-1}$ ), chloride concentration $\left(\mathrm{Cl}^{-}\right.$; from 500 to $\left.1000 \mathrm{mg} \cdot \mathrm{L}^{-1}\right)$, and sodium concentration $\left(\mathrm{Na}^{+}\right.$; from 250 to $\left.2700 \mathrm{mg} \cdot \mathrm{L}^{-1}\right)$ as a result of seawater intrusion (Segura et al., 2009). These waters are conventionally classified as having moderate to severe restrictions for the irrigation of crops (Ayers and Westcot, 1987).

Because of the importance of the production of tomatoes in greenhouses in the Mediterranean area it is important to determine

Received for publication 20 Nov. 2017. Accepted for publication $13 \mathrm{Feb} .2018$.

${ }^{1}$ Corresponding author. E-mail: marial.segura@, juntadeandalucia.es. aggregates these comparisons into a series of nutrient indices (Abd El-Rheem et al., 2015). The DRIS indices enable the evaluation of the nutritional balance of a plant, ranking nutrient levels in relative order; when a nutrient index is negative (below zero), this means there is a nutrient deficiency and when a nutrient index is positive, this indicates nutrient excess, as proposed by Beaufils (1973). The calculation of the DRIS indexes (there is an index for each nutrient) depends, initially, on the establishment of standard values or reference norms for each dual relationship between each pair of nutrients.

The DRIS norms consist of the mean, the variance, and the $\mathrm{CV}$ of the dual ratio between nutrients $(\mathrm{N} / \mathrm{P}, \mathrm{P} / \mathrm{N}, \mathrm{N} / \mathrm{K}, \mathrm{K} / \mathrm{N}$, etc.) obtained from a crop reference population that shows a high yield and quality objectives reached (Beaufils, 1973). The data bank to compose the DRIS norms is formed by the crop yield and chemical analysis of leaf tissue, and this information can be obtained from commercial crops or experimental units. The size of the data bank is not a factor which is directly related to the quality of the DRIS norms (Walworth et al., 1988). The method to select the form of ratio for a pair of nutrients to be used in DRIS calculation is described by Walworth and Sumner (1987) and Nick (1998).

The DRIS can be less sensitive than the sufficiency range approach, due to differences caused by leaf position, tissues age, climate, soil conditions, and the cultivar effect because nutrient ratios were used (Sanchez et al., 1991). Nevertheless, the different requirements of the plants associated with their phenological stage and the environmental conditions may affect the validity of defined standard DRIS norms (without consideration of the phenological stage) (Beaufils, 1973), as proposed in a tomato crop by Caront and Parent (1989).

DRIS evaluation has been used and conducted on different horticultural crops (Angeles et al., 1993; Beverly, 1991; Bottoms et al., 2013; Hartz et al., 2007). However, information concerning tomato crops in this area is limited, but some DRIS norms in tomato have been conducted by different authors in others countries (Abd El-Rheem et al., 2015; Caront and Parent, 1989; Hartz et al., 1998). Because of the importance of the tomato crop in the Mediterranean climate area, the objectives of this study were to compute DRIS norms and sufficiency ranges from a survey of tomato crops grown in greenhouses in the southeast of Spain and the verification of the variation in DRIS norms and sufficiency ranges during plant growth and development.

\section{Material and Methods}

Data source. This study was performed with the data from experimental and commercial greenhouses in different years (from 1984 to 2005) which grew tomatoes in southeast Spain (Almería) during the growing season of autumn-winter. The climatic parameters outside of the greenhouse were 
provided by the agroclimatic station of the Institute of Research and Training in Agriculture and Fishery (IFAPA), Junta of Andalusia, La Mojonera, Almería, Spain. During the autumn-winter growing season, the maximum and minimum temperature ranged from 27 to $9{ }^{\circ} \mathrm{C}$. The maximum and minimum relative humidity ranged from $84 \%$ to $41 \%$ and the global radiation ranged from 9 to $20 \mathrm{MJ} \cdot \mathrm{m}^{-2}$. The soil used in this study was a mulching sandy soil described by Segura (1995) and Lao (2004). The main characteristics of the mulching sandy soil are the following: it is constituted by a layer of gravel-sand with variable granulometry composed of particles (size from $<1$ to $5 \mathrm{~mm}$ ), an intermediate layer of organic matter usually forming a layer or mixed wholly or partially with the topsoil, and the natural soil with a variable texture varying from clay to sandy loam. All the cultivars of tomato crop were grown with a planting density of 2 plants $/ \mathrm{m}^{2}$ and fertigated with drippers of $3 \mathrm{~L} \cdot \mathrm{h}^{-1}$.

Choice of plots. The selection of the reference population is an important factor for the effectiveness and success of the DRIS. The reference group with a production range of $9.2-13.5 \mathrm{~kg} \cdot \mathrm{m}^{-2}$, was acceptable for production in this area with a mean production of $9.56 \mathrm{~kg} \cdot \mathrm{m}^{-2}$ (Valera et al., 2016). The production range of the reference group is related to the duration of the tomato crop cycle. The reference group presents a normal distribution as recommended by Walworth and Sumner (1987).

Database. To constitute the database, 408 samples of first young mature leaves from Solanum lycopersicum L., type round ('Rambo', 'Carmelo', 'Buffalo', 'Daniela', and 'Pitenza') were collected at different phenological stages from different monitored crop cycles: FL (36), fruiting (FT) (38), FD (59), maturity (MT) (47) and harvesting (HV) (228). Leaf samples were composed of 15-30 healthy and fully developed leaves chosen from various plants (one leaf sample per plant) in the plot. In the laboratory, the leaves were washed and the petioles were removed. The samples were dried in an air-forced drying oven at $70{ }^{\circ} \mathrm{C}$ for $24 \mathrm{~h}$, until constant weight was attained. Then, they were pulverized and sifted through an 80-micron mesh sieve and homogenized (Hernando and Cadahía, 1973). Lastly, they were preserved in airtight polyvinyl chloride containers, sealed with paraffin, and stored in a dark, dry place (MAPA, 1986). Each sample was divided into two subsamples; one was ashed at $450{ }^{\circ} \mathrm{C}$ $(4 \mathrm{~h})$ and diluted with hydrochloric acid $(\mathrm{HCl}$ $6 \mathrm{~N})$ solution. Total $\mathrm{P}$ concentration in the acid solution was determined by the phosphovanadomolybdate method, and total potassium $(\mathrm{K})$, calcium $(\mathrm{Ca})$, and magnesium $(\mathrm{Mg})$ were determined by atomic absorption spectrometry (MAPA, 1986). The other subsample was digested with sulfuric acid $\left(\mathrm{H}_{2} \mathrm{SO}_{4}, 96 \%\right)$ and used to directly determine total $\mathrm{N}$ by the Kjeldahl digestion procedure (Ma and Zuazaga, 1942).

Development of DRIS norms. To choose the representative ratio between each pair of nutrients, the criteria proposed by Nick (1998) called the " $R$ value" was selected. This consists of the calculation of the correlation coefficient $(r)$ among the productivity values obtained along with the relationships between the pairs of nutrients, either in inverse or direct order. The order of the ratio that presents the largest absolute value of the coefficient of correlation $(r)$ is selected:

$$
\begin{aligned}
& \text { If : }|r A / B|>|r B / A| \text { then }: \text { ratio in the norm } \\
& \quad=A / B
\end{aligned}
$$

If : $|r A / B|<|r B / A|$ then : ratio in the norm

$$
=B / A \text {, }
$$

where $|r A / B|$ is the absolute value of the correlation coefficient between productivity and the $A / B$ ratio (ratio among the concentrations of two nutrients $A$ and $B$ of the population); $|r B / A|$ and $B / A$ are the same as previously mentioned for nutrients $B$ and $A$ in inverse order. The order of the relationship that presents the largest absolute value of the correlation coefficient $(r)$ is selected. In the selection of the reference ratio order only the database of HV was used.

Sufficiency ranges. The optimum leaf range in tomato plants was determined using the DRIS technique. In fact, DRIS technique used the average value of each element $(\mathrm{N}, \mathrm{P}$, $\mathrm{K}$, etc.) obtained from the mineral composition of leaf tissues of the reference population as a reference value, thus establishing the sufficiency average. The optimum ranges are the values obtained from the average $\pm 4 / 3$ of SD of the reference population (Beaufils, 1971; Beaufils and Sumner, 1976; Bhargava, 2002). With the use of this technique, two sufficiency ranges were developed: one includes the entire database and the other was based only according to each phenological stage.

Statistical analysis. Correlation $(r)$ coefficients were computed $(P<0.01)$ to measure the strength of the relationship between these variables. The analysis of variance and the least significant difference tests $(P<0.05)$ were used to assess the differences between phenological stages. All statistical analyses were performed using Statgraphics Plus for Windows (version 5.1; Statpoint Technologies, Warrenton, VA).

\section{Results}

Development of DRIS norms. The means for each ratio, $\mathrm{CV}$ population with productivity values, and correlation coefficients of macronutrient ratios of the reference population are shown in Table 1. The values in bold correspond to the ratios among the nutrients selected. It is worth noting that some of the coefficients of correlation of the nutrients ratio showed a lower relationship with the fruit productivity. Only the relationships N/P, $\mathrm{N} / \mathrm{K}, \mathrm{K} / \mathrm{Ca}, \mathrm{Ca} / \mathrm{P}$, and $\mathrm{Mg} / \mathrm{K}$ were greater than 0.30 . In some cases, the choice of the relationship was accomplished using a very low correlation coefficient $(\mathrm{N} / \mathrm{Ca}, \mathrm{P} / \mathrm{K}, \mathrm{P} / \mathrm{Mg}$, $\mathrm{Mg} / \mathrm{N}$, and $\mathrm{Mg} / \mathrm{Ca}$ ).
Table 1. DRIS norms (mean, cv, and correlation coefficient).

\begin{tabular}{lrcr}
\hline Norms & Mean & CV $(\%)$ & $r$ \\
\hline $\mathrm{N} / \mathrm{P}$ & 10.45 & 35 & $-0.47^{* *}$ \\
$\mathrm{~N} / \mathrm{K}$ & 1.54 & 41 & $-0.31^{* *}$ \\
$\mathrm{~N} / \mathrm{Ca}$ & 1.13 & 40 & $0.15^{* *}$ \\
$\mathrm{P} / \mathrm{K}$ & 0.16 & 48 & $0.12^{* *}$ \\
$\mathrm{P} / \mathrm{Mg}$ & 0.43 & 66 & $0.21^{* *}$ \\
$\mathrm{~K} / \mathrm{Ca}$ & 0.84 & 42 & $0.41^{* *}$ \\
$\mathrm{Ca} / \mathrm{P}$ & 10.01 & 39 & $-0.48^{* *}$ \\
$\mathrm{Mg} / \mathrm{N}$ & 0.32 & 56 & $0.17^{* *}$ \\
$\mathrm{Mg} / \mathrm{K}$ & 0.41 & 30 & $-0.39^{* *}$ \\
$\mathrm{Mg} / \mathrm{Ca}$ & 0.31 & 33 & $0.24 * *$ \\
**Indicates significant differences at $P \leq 0.01$
\end{tabular}

The means and CV of DRIS norms divided by the phenological stage are shown in Table 2. In our results, the means values range were N/P (10.45-13.20), N/K (1.522.47), N/Ca (1.10-2.09), P/K (0.15-0.25), $\mathrm{P} / \mathrm{Mg}(0.28-0.62), \mathrm{K} / \mathrm{Ca}(0.47-1.34), \mathrm{Ca} / \mathrm{P}$ (6.37-12.74), $\mathrm{Mg} / \mathrm{N} \quad(0.17-0.26), \quad \mathrm{Mg} / \mathrm{Ca}$ $(0.22-0.38)$, and $\mathrm{Mg} / \mathrm{K}(0.28-0.62)$. Significant differences were found in all ratios when compared with the different phenological stages of the plants. It was remarkable that FL showed the lowest CV of all phenological stages, ranging from $8 \%(\mathrm{P} / \mathrm{Mg})$ to $15 \%$ $(\mathrm{K} / \mathrm{Ca})$, whereas in $\mathrm{FT}$ the lowest $\mathrm{CV}$ was $\mathrm{P} / \mathrm{K}$ $(30 \%)$ and the highest $\mathrm{CV}$ was $\mathrm{P} / \mathrm{Mg}(58 \%)$. In fruit development, the ratios of $\mathrm{N} / \mathrm{K}$ and $\mathrm{Ca} / \mathrm{P}$ showed the lowest and the highest $\mathrm{CV}(17 \%$ and $53 \%$, respectively). In the case of $\mathrm{MT}$ and $\mathrm{HV}$, the N/P ratio was the lowest (28\% and $35 \%$, respectively) and the highest were $\mathrm{Mg} / \mathrm{K}$ for $\mathrm{MT}(62 \%)$ and $\mathrm{P} / \mathrm{Mg}$ for HV $(66 \%)$.

General nutrient sufficiency ranges, for all the growing stages of tomato plants derived from DRIS techniques using the complete data bank are shown in Table 3 . The sufficiency ranges were $\mathrm{N}(26-48), \mathrm{P}(2.6-4.7)$, $\mathrm{K}(16-27), \mathrm{Ca}(23-36)$, and $\mathrm{Mg}\left(6.7-10 \mathrm{~g} \cdot \mathrm{kg}^{-1}\right)$, respectively. All the nutrients showed normal distribution. Considering these sufficiency ranges of the complete dataset of tomato samples were between the sufficiency ranges for each nutrient $[71 \%(\mathrm{~N}), 70 \%(\mathrm{P}), 79 \%(\mathrm{~K})$, $83 \%(\mathrm{Ca})$, and $80 \%(\mathrm{Mg})]$, respectively.

Table 4 showed the sufficiency ranges for each nutrient at the different growth stages of the plant, showing a normal distribution in all the data in different development stages. The optimal ranges delivered by the DRIS technique showed the lowest concentration ranges for $\mathrm{N}, \mathrm{P}$, and $\mathrm{K}$ in HV. On the contrary, $\mathrm{Ca}$ and $\mathrm{Mg}$ showed the lowest concentration ranges concentration in FL. In addition, the highest value of $\mathrm{N}$ was in FL, whereas for $\mathrm{P}$ and $\mathrm{K}$ it was in fruit development, and for $\mathrm{Ca}$ and $\mathrm{Mg}$ in MT; considering these sufficiency ranges, $70 \%$ to $92 \%$ of tomato leaves samples were sufficient in all the growth stages. When comparing Table 3 with Table 4 , it can be observed that sometimes the nutrients can be slightly above or below the optimal range, and it is also noteworthy that in some of the cases the optimal ranges divided by the growth stages were more restrictive than the ranges reported for all stages of plant development. 
Table 2. Diagnosis and recommendation integrated system norms in different phenological stages. Means with different letters in the same row indicate significant differences between the different phenological stages (least significant difference test at $P \leq 0.01$ ). Flowering (FL), fruiting (FT), fruit development (FD), maturity (MT), and harvesting (HV).

\begin{tabular}{|c|c|c|c|c|c|c|c|c|c|c|}
\hline \multirow[b]{2}{*}{ Norms } & \multicolumn{2}{|c|}{ FL } & \multicolumn{2}{|c|}{ FT } & \multicolumn{2}{|c|}{ FD } & \multicolumn{2}{|c|}{ MT } & \multicolumn{2}{|c|}{$\mathrm{HV}$} \\
\hline & Mean & $\mathrm{CV}(\%)$ & Mean & $\mathrm{CV}(\%)$ & Mean & $\mathrm{CV}(\%)$ & Mean & $\mathrm{CV}(\%)$ & Mean & $\mathrm{CV}(\%)$ \\
\hline$\overline{\mathrm{N}} / \mathrm{P}$ & $13.20 \mathrm{a}$ & 12 & $11.27 \mathrm{ab}$ & 49 & $11.40 \mathrm{ab}$ & 35 & $11.06 \mathrm{~b}$ & 28 & $10.45 \mathrm{~b}$ & 35 \\
\hline $\mathrm{N} / \mathrm{K}$ & $2.00 \mathrm{~b}$ & 11 & $1.76 \mathrm{cb}$ & 30 & $1.52 \mathrm{c}$ & 17 & $2.47 \mathrm{a}$ & 32 & $1.54 \mathrm{c}$ & 41 \\
\hline $\mathrm{N} / \mathrm{Ca}$ & $2.09 \mathrm{a}$ & 13 & $1.47 \mathrm{~b}$ & 39 & $2.05 \mathrm{a}$ & 30 & $1.10 \mathrm{c}$ & 58 & $1.13 \mathrm{c}$ & 40 \\
\hline $\mathrm{P} / \mathrm{K}$ & $0.15 \mathrm{~b}$ & 9 & $0.18 \mathrm{~b}$ & 30 & $0.15 \mathrm{~b}$ & 36 & $0.25 \mathrm{a}$ & 53 & $0.16 \mathrm{~b}$ & 48 \\
\hline $\mathrm{K} / \mathrm{Ca}$ & $1.05 \mathrm{~b}$ & 15 & $0.85 \mathrm{c}$ & 38 & $1.34 \mathrm{a}$ & 39 & $0.47 \mathrm{~d}$ & 54 & $0.84 \mathrm{c}$ & 42 \\
\hline $\mathrm{Ca} / \mathrm{P}$ & $6.37 \mathrm{~d}$ & 12 & $8.49 \mathrm{c}$ & 53 & $6.45 \mathrm{~d}$ & 53 & $12.74 \mathrm{a}$ & 51 & $10.01 \mathrm{~b}$ & 38 \\
\hline $\mathrm{Mg} / \mathrm{N}$ & $0.17 \mathrm{~d}$ & 8 & $0.24 \mathrm{cb}$ & 35 & $0.19 \mathrm{dc}$ & 25 & $0.26 \mathrm{~b}$ & 57 & $0.32 \mathrm{a}$ & 55 \\
\hline $\mathrm{P} / \mathrm{Mg}$ & $0.44 \mathrm{bc}$ & 8 & $0.50 \mathrm{ab}$ & 58 & $0.54 \mathrm{a}$ & 32 & $0.53 \mathrm{ab}$ & 61 & $0.43 \mathrm{c}$ & 66 \\
\hline $\mathrm{Mg} / \mathrm{K}$ & $0.35 \mathrm{bc}$ & 9 & $0.41 \mathrm{~b}$ & 35 & $0.28 \mathrm{c}$ & 22 & $0.62 \mathrm{a}$ & 62 & $0.41 \mathrm{~b}$ & 30 \\
\hline $\mathrm{Mg} / \mathrm{Ca}$ & $0.36 \mathrm{ab}$ & 13 & $0.32 \mathrm{bc}$ & 32 & $0.38 \mathrm{a}$ & 47 & $0.22 \mathrm{~d}$ & 32 & $0.31 \mathrm{c}$ & 33 \\
\hline
\end{tabular}

Table 3. Comparative study of general ranges DRIS delivered optimum foliar nutrient concentration ranges for tomato with published sufficiency ranges.

\begin{tabular}{|c|c|c|c|c|c|}
\hline & $\mathrm{N}$ & $\mathrm{P}$ & $\mathrm{K}$ & $\mathrm{Ca}$ & $\mathrm{Mg}$ \\
\hline & \multicolumn{5}{|c|}{ 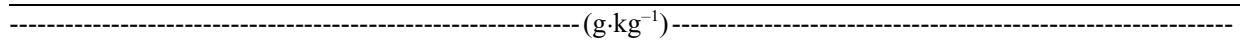 } \\
\hline DRIS sufficiency & $25-48$ & $2.6-4.7$ & $16-31$ & $23-36$ & $6.7-10$ \\
\hline Guzmán (1987) & $37-39$ & $2.8-3.1$ & $25-28$ & $28-30$ & $5.3-5.5$ \\
\hline Casas and Casas (1999) & $35-50$ & $3.0-7.0$ & $35-55$ & $18-35$ & $4.0-8.0$ \\
\hline Nuez (1995) & $41-58$ & $2.0-5.0$ & $15-25$ & $23-40$ & $6.0-11$ \\
\hline Scucuglia and Creste (2014) & $29-44$ & $4.0-7.0$ & $35-51$ & $19-35$ & $4.0-8.0$ \\
\hline
\end{tabular}

DRIS $=$ diagnosis and recommendation integrated system.

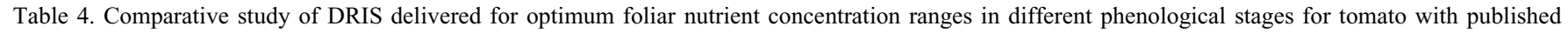
sufficiency ranges. Flowering (FL), fruiting (FT), fruit development (FD), maturity (MT), and harvesting (HV).

\begin{tabular}{|c|c|c|c|c|c|c|}
\hline & & $\mathrm{N}$ & $\mathrm{P}$ & $\mathrm{K}$ & $\mathrm{Ca}$ & $\mathrm{Mg}$ \\
\hline & & \multicolumn{5}{|c|}{ - } \\
\hline \multirow[t]{3}{*}{$\overline{\mathrm{FL}}$} & DRIS sufficiency & $45-55$ & $3.4-4.2$ & $22-28$ & $21-27$ & $8.1-9.1$ \\
\hline & Cadahía (2008) & $45-60$ & $2.0-5.0$ & $16-21$ & $24-34$ & $8.0-15$ \\
\hline & Hochmuth et al. (1991) & $28-40$ & $2.0-4.0$ & $25-40$ & $10-20$ & $3.0-5.0$ \\
\hline \multirow[t]{3}{*}{ FT } & DRIS sufficiency & $24-50$ & $2.2-5.3$ & $17-27$ & $17-39$ & $4.9-11$ \\
\hline & Cadahía (2008) & $43-56$ & $2.6-4.0$ & $18-25$ & $26-49$ & $6.5-11$ \\
\hline & Hochmuth et al. (1991) & $25-45$ & $2.0-4.0$ & $25-40$ & $10-20$ & $2.5-5.0$ \\
\hline \multirow[t]{3}{*}{ FD } & DRIS sufficiency & $39-51$ & $2.6-6.3$ & $24-38$ & $16-34$ & $5.5-11$ \\
\hline & Cadahía (2008) & $36-58$ & $1.8-5.0$ & $12-25$ & $20-31$ & $4.0-10$ \\
\hline & Hochmuth et al. (1991) & - & - & - & - & - \\
\hline \multirow[t]{3}{*}{ MT } & DRIS sufficiency & $31-51$ & $2.6-5.3$ & $10-26$ & $23-51$ & $5.0-14$ \\
\hline & Cadahía (2008) & - & - & - & - & - \\
\hline & Hochmuth et al. (1991) & $20-35$ & $2.0-4.0$ & $20-40$ & $10-20$ & $2.5-5.0$ \\
\hline \multirow[t]{3}{*}{ HV } & DRIS sufficiency & $20-39$ & $1.9-3.3$ & $14-29$ & $17-37$ & $5.0-11$ \\
\hline & Cadahía (2008) & $39-60$ & $2.0-5.0$ & $12-28$ & $24-47$ & $4.0-11$ \\
\hline & Hochmuth et al. (1991) & $20-30$ & $2.0-4.0$ & $15-25$ & $10-20$ & $2.5-5.0$ \\
\hline
\end{tabular}

DRIS = diagnosis and recommendation integrated system

\section{Discussion}

The norms derived from this work have a broad database with different types of soil and varieties that generate a representative population variability as proposed by Mourão-Filho (2004). Nevertheless, in agreement with previous research concerning DRIS with high variability during the crop because of the phenological stage, in our work we compute the DRIS norms following the model of different growth stages proposed by Caront and Parent (1989).

The variability of DRIS norms (cv) within sampling periods is attributable to the varietal ability to uptake and use nutrients (English and Barker, 1987); climatic conditions and the nutrient solution concentration (Segura et al., 2009); and photosynthetic irradiance and root-zone temperature (Tremblay et al., 1988). A lower value of $\mathrm{CV}$ from the norms obtained with the DRIS technique means that a slight modification in the nutrient concentration led to a great change in the nutritional balance as proposed by Junior et al. (2003). In the DRIS norms, all the relationships between nutrients in FL have a low CV, agreeing with Caront and Parent (1989) and Hartz et al. (1998) who also reported lower values of $\mathrm{CV}$ in the early stages of the tomato crop. The lower values of $\mathrm{CV}$ in the relationships between nutrients in FL maybe because of the FL stage; a nutritional imbalance can severely affect plant growth in the future and therefore, this can be considered a nutritionally critical state in plant development.

Similar to $\mathrm{FL}$, the ratios of $\mathrm{N} / \mathrm{K}, \mathrm{Mg} / \mathrm{N}$, and $\mathrm{Mg} / \mathrm{K}$ in fruit development showed lower CV $(17 \%, 25 \%$, and $22 \%$, respectively), agreeing, in part, with the $\mathrm{CV}$ values for the same ratios proposed by Caront and Parent (1989) $(13 \%, 13 \%$, and $13 \%$, respectively). The N/K ratio maybe important because of the increase of these nutrients requirements in FD (Bugarín-Montoya et al., 2002) and consequently, any deficit of an element can have a negative impact on the growth and yield of tomato (Bugarín-Montoya et al., 2002; Fayad et al., 2002). In the case of $\mathrm{Mg} / \mathrm{K}$, the relationship between both elements is important because of the antagonism of these elements in the plant (Mengel and Kirkby, 1987). On the other hand, the $\mathrm{Mg} / \mathrm{N}$ relationship maybe because both nutrients share a relationship with $\mathrm{K}$.

In Table 3, the sufficiency ranges for optimum foliar nutrients are compared with other authors. Guzmán (1987), Casas and Casas (1999), and Nuez (1995) reported optimum values obtained in the same area, and Scucuglia and Creste (2014) reported values for tomato in greenhouses in Brazil. In this experiment, the $\mathrm{N}$ range is similar to those obtained by most of the authors, nevertheless, Nuez (1995) presented higher values. Also, Casas and Casas (1999) presented the 
highest values of $\mathrm{P}$ and $\mathrm{K}$ which can be related to the inclusion of the petiole in samples in these experiment, because the petiole presents a higher and more variable content of nutrients (such as $\mathrm{P}$ and $\mathrm{K}$ ) than the leaf blade. This fact, can lead to errors when interpreting the results if both tissues are included in the sample (Jones, 1998). In the same way, the highest values of $\mathrm{P}$ (Scucuglia and Creste, 2014) maybe related to the better temperature conditions of the experiment. Kafkafi et al. (1984) proposed that $\mathrm{P}$ uptake was strongly affected by low temperature. In the case of $\mathrm{Ca}$ and $\mathrm{Mg}$, similar ranges have been found by other authors (Casas and Casas, 1999; Guzmán, 1987; Nuez, 1995; Scucuglia and Creste, 2014).

Table 4 shows the sufficiency ranges following individual nutrient concentration for each phenological stage where optimum foliar nutrient was delivered after the DRIS method compared with the concentrations established by other authors (Cadahía, 2008; Hochmuth et al., 1991). Attending Table 4, we can observe that, the optimum ranges delivered by DRIS were similar to those proposed by Cadahía (2008) and Hochmuth et al. (1991). Nevertheless, higher values of $\mathrm{Ca}$ and $\mathrm{Mg}$ were found than those proposed by Hochmuth et al. (1991) in all the phenological stages and this maybe due to the soil composition in this area, which has a high level of both elements (Lao, 2002). The lowest range values of $\mathrm{N}, \mathrm{P}$, and $\mathrm{K}$ in $\mathrm{HV}$ compared with the other stages of development maybe due to the dilution factor of these nutrients (Marschner, 2011). Also, the highest values of $\mathrm{Ca}$ and $\mathrm{Mg}$ in MT maybe related to the increase in $\mathrm{Ca}$ and $\mathrm{Mg}$ uptake in the mature period as proposed by Carpena et al. (1988). The variability of sufficiency ranges in different phenological stages is attributable to the origin of the dataset and other factor variabilities, such as varietal differences in the uptake and use of nutrients; climatic conditions and the nutrient solution concentration; and photosynthetic irradiance and root-zone temperature; as happens in DRIS norms.

In conclusion, the DRIS norms presented in this article could improve the nutritional diagnosis of greenhouse tomato. DRIS norms and sufficiency ranges were sensitive to plant developmental stages. The sufficiency ranges developed in this study could be used in the Mediterranean area and in regions with similar edapho-climatic conditions and production systems.

\section{Literature Cited}

Abd El-Rheem, K.M., M. Entsar, A. Hayam, and A. Mahdy. 2015. Preliminary DRIS norms for evaluating the nutritional status for tomato crop. Adv. Agr. Biol. 4:50-53.

Adams, P. 1986. Mineral nutrition, p. 281-334. In: The tomato crop. Springer, Dordrecht, The Netherlands.

Angeles, D.E., M.E. Sumner, and E. Lahav. 1993. Preliminary DRIS norms for banana. J. Plant Nutr. 16:1059-1070.

Ayers, R.S. and D.W. Westcot. 1987. Water quality for the agriculture. (Irrigation and drainage, no. 29). FAO, Rome, Italy.
Beaufils, E.R. 1971. Physiological diagnosis: A guide for improving maize production based on principles developed for rubber trees. Fert. Soc. S. Afr. J. 1:1-28.

Beaufils, E.R. 1973. Diagnosis and recommendation integrated system (DRIS). A general scheme of experimentation and calibration based on principles developed from research in plant nutrition. Univ. Natal, Pietermaritzburg, South Africa.

Beaufils, E.R. and M.E. Sumner. 1976. Application of DRIS approach for calibrating soil, plant yield and plant quality factors of sugarcane Proc. S. Afr. Sugar Tech. Assoc. 50:118-124.

Beverly, R.B. 1991. A practical guide to the diagnosis and recommendation integrated system (DRIS). Micro-Macro Intl., Athens, GA.

Bhargava, B.S. 2002. Leaf analysis for nutrient diagnosis, recommendation and management in fruit crops. J. Indian Soc. Soil Sci. 50:352-373.

Bottoms, T.G., M.P. Bolda, M.L. Gaskell, and T.K. Hartz. 2013. Determination of strawberry nutrient optimum ranges through diagnosis and recommendation integrated system analysis. HortTechnology 23:312-318.

Bugarín-Montoya, R., A. Glavis-Spinola, P. SánchezGarcía, and D. García-Paredes. 2002. Daily accumulation of aboveground dry matter and potassium in tomato (in Spanish, with English abstr.). Terra 20:401-409.

Cadahía, C. 2008. Fertigation. Sap as an index of fertigation in agroenergy, horticultural, fruit and ornamental crops. Mundi-Prensa, Madrid, Spain.

Cabrera, A., D. Uclés, T. Agüera, and E. de la Cruz. 2016. Análisis de la campaña hortofrutícola de Almería Campaña 2015/2016. Almería, Spain.

Caront, J. and L.E. Parent. 1989. Derivation and assessment of DRIS norms for greenhouse tomatoes. Can. J. Plant Sci. 69:1027-1035.

Carpena, O., A.M. Rodríguez, and M.J. Sarro. 1988. Nutrient uptake by two cultivars of tomato plants. Plant Soil 105:294-296.

Casas, A. and E. Casas. 1999. Soil-water-plant analysis and their application in the nutrition of horticultural crops in the southeastern of Almeria. Ed. Caja Rural Almeria, Almeria, Spain.

English, J.E. and A.V. Barker. 1987. Ion interactions in $\mathrm{Ca}$-efficient and $\mathrm{Ca}$-inefficient tomato lines. J. Plant Nutr. 10:857-869.

Fayad, J., P. Fontes, A. Cardoso, F. Finger, and F. Ferreira. 2002. Nutrient absorption by tomato plants grown under field and protected conditions. Hort. Bras. 20:90-94.

Hallmark, W. B. and Beverly, R. B. 1991. Review: An update in the use of the diagnosis and recommendation integrated system. J. Fer. Issues 8:74-88.

Hartz, T.K., P.R. Johnstone, E. Williams, and R.F. Smith. 2007. Establishing lettuce leaf nutrient optimum ranges through DRIS analysis. HortScience 42:143-146.

Hartz, T.K., E.M. Miyao, and J.G. Valencia. 1998 DRIS evaluation of the nutritional status of processing tomato. HortScience 33:830-832.

Hernando, V. and C. Cadahía. 1973. El análisis de savia como índice de fertilización. CSIC, Instituto de Edafología y Biología Vegetal, Madrid, Spain.

Hochmuth, G., D. Maynard, C. Vavrina, and E. Hanlon. 1991. Plant tissue analysis and interpretation for vegetable crops in Florida. Florida Coop. Ext. Spec. Ser. SS-VEC-42, Gainesville, FL.

Guzmán, J.M. 1987. Nutritional balance in greenhouse conditions: Correction and improvement of harvesting (in Spanish). Univ. Granada, Spain, PhD Diss.
Jones, J.B. 1998. Plant nutrition manual. CRC Press, Boca Raton, FL.

Junior, R., R. dos Anjos, and P.H. Monnerat. 2003. DRIS norms validation for sugarcane crop. Pesqui. Agropecu. Bras. 38:379-385.

Kafkafi, U., E. Dayan, and B. Akiri. 1984. Nitrate and phosphate uptake by tomato from nutrient solution in a commercial operation. Intl. Soc. Soilless Cult. 291-299.

Lao, M.T. 2002. Fertigation management in the greenhouses from Almeria by means of suction cups (in Spanish). Univ. Almería, Spain, PhD Diss.

Lao, M.T. 2004. The mulching sandy soil and their management fertigation in horticultural production. Trends Soil Sci. 3:71-82.

Ma, T. and G. Zuazaga. 1942. Micro-Kjeldahl determination of nitrogen. A new indicator and an improved rapid method. Ind. Eng. Chem. Anal. Ed. 14:280-282.

MAPA. 1986. Métodos Oficiales de análisis. Tomo III. Secretaría General Técnica del Ministerios de Agricultura, Pesca y Alimentación, Madrid, Spain.

Marschner, H. 2011. Marschner's mineral nutrition of higher plants. 3rd ed. Academic Press, Harcourt Brace and Company, Publishers, San Diego, CA.

Mengel, K. and E.A. Kirkby. 1987. Principles of plant nutrition. 4th ed. Intl. Potash Inst., Bern, Switzerland.

Mourão-Filho, F.D.A.A. 2004. DRIS: Concepts and applications on nutritional diagnosis in fruit crops. Scientia Agr. 61:550-560.

Nick, J.A. 1998. DRIS for coffee plants (in Portuguese). Piracicaba: USP/ESALQ, Brazil, Diss.

Nuez, F. 1995. El cultivo de tomate. Ediciones Mundi-Prensa, Madrid, Spain.

Sanchez, C.A., G.H. Sera, and H.W. Burdine. 1991. DRIS Evaluation of the nutritional status of crisphead lettuce. HortScience 26:274-276.

Scucuglia, C.L. and J.E. Creste. 2014. Diagnosis and recommendation integrated system (DRIS) of tomato in greenhouse. Hort. Bras. 32:200-204.

Segura, M.L. 1995. Fertigation vegetable crops in saline conditions with mulching sandy soil system and alternative substrates in the agricultural region of Almería (in Spanish). Universidad Autónoma, Madrid, Spain, PhD Diss.

Segura, M.L., J.I. Contreras, R. Salinas, and M.T. Lao. 2009. Influence of salinity and fertilization level on greenhouse tomato yield and quality. Commun. Soil Sci. Plant Anal. 40: 485-497.

Stark, J.R., J. Grudzinska-Kiihn, and J. Wojciechowski. 1973. Leaf analysis as a means of determining the nutrient requirements of greenhouse tomatoes. Acta Hort. 29:81-88.

Sumner, M.E. 1979. Interpretation of foliar analysis for diagnostic purposes. Agron. J. 71:343-348.

Tremblay, N., M.C. Gasia, M.T. Ferauge, A. Gosselin, and M.J. Trudel. 1988. Influence of photosynthetic irradiance on nitrate reductase activity, nutrient uptake and partitioning in tomato plants. J. Plant Nutr. 11:17-36.

Valera, D.M., L. Belmonte, F.D. Molina, and A. López. 2016. Greenhouse agriculture in Almería: A comprehensive techno-economic analysis. Cajamar Caja Rural, Almería, Spain.

Walworth, J.L. and M.E. Sumner. 1987. The diagnosis and recommendation integrated system (DRIS). In: Advances in soil science. Springer, New York, NY.

Walworth, J.L., H.J. Woodard, and M.E. Sumner. 1988. Generation of corn tissue norms from a small, high-yield data base. Commun. Soil Sci. Plant Anal. 19:563-577. 